\title{
The Effects of Dietary Flavonoid Supplementation on the Antioxidant Status of Laying Hens
}

http://dx.doi.org/10.1590/1806-9061-2016-0356

\section{-Author(s)}

\author{
Iskender $\mathrm{H}^{\prime}$ \\ Yenice G" \\ Dokumacioglu $\mathrm{E}^{\prime}$ \\ Kaynar O"II \\ Hayirli A" \\ Kaya A ${ }^{\mathrm{IV}}$
}

Department of Nutrition and Dietetics, Faculty of Health Sciences, Artvin Coruh University, Artvin 08000, Turkey

" Department of Animal Nutrition and Nutritional Disorders, Faculty of Veterinary Medicine, Ataturk University, Erzurum 25240, Turkey

III Department of Biochemistry, Faculty of Veterinary Medicine, Ataturk University, Erzurum 25240, Turkey

IV Department of Animal Sciences, Agricultural Faculty, Ataturk University, Erzurum 25240, Turkey

\section{-Mail Address}

Corresponding author e-mail address Hatice Iskender

Department of Nutrition and Dietetics, Faculty of Healthy Sciences, Artvin Coruh University, Artvin, Dogu Karadeniz, Turkey. Zip code: 08000

Tel: $\quad$ (+90) 5433171719

Email: haticeiskender2011@hotmail.com

\section{nKeywords}

Antioxidant, Flavonoid, Hesperidin, Naringin Quercetin.

\section{ABSTRACT}

Ninety-six 28-week-old Lohmann White laying hens were utilized to test the antioxidant effects of flavonoids (hesperidin, naringin, and quercetin at $0.5 \mathrm{~g} / \mathrm{kg}$ diet) during an $8-\mathrm{wk}$ experimental period. At the end of the experiment blood samples were collected to determine total protein, cholesterol, and malondialdehyde (MDA) serum levels as well as activities of glutathione reductase (GR), glutathione peroxidase (GSH-Px), glutathione-S-transferase (GST), and superoxide dismutase (SOD) and level of glutathione (GSH) in erythrocyte lysates. Data were analyzed using one-way ANOVA. Naringin supplementation did not alter serum cholesterol concentration, whereas hesperidin and quercetin supplementations decreased serum cholesterol concentration. Naringin and quercetin supplementations did not affect serum protein concentration. All flavonoids decreased MDA concentration as well as increased GSH-Px, GR, GST, and SOD activities and GSH level, being quercetion superior to hesperidin and naringin. In conclusion, flavonoids, especially quercetin, exert antioxidant activity, which may help improve wellbeing when laying hens are exposed to stressors.

\section{INTRODUCTION}

Poultry meat and eggs are cheap and valuable foods for human nutrition. The demand for these foods is likely to increase as the global population increases (Florou-Paneri et al., 2005). At a farm level, bird health is critical to maximize production efficiency (reducing mortality, eliminating diseases and treatment costs, and improving feed efficiency). Due to public health concerns regarding antibiotic resistance and residue issues, the use of antimicrobial agents to improve productivity has been banned (Ertaş et al., 2005). Various alternative feed additives have been tested to improve the feed efficiency and to enhance the health status of poultry, and are expected to exert antimicrobial, antioxidant, and immune-enhancing activities and be retained in the poultry products (Abdel-Rahman et al., 2013; Kamboh et al., 2015).

Defense systems in the body that prevent damages caused by reactive oxygen species (ROS) during exposure to infections, inflammation, and stressors are called antioxidant defense systems. Antioxidants prevent lipid peroxidation by blocking peroxidation chain reactions and acting as ROS scavengers (Valko et al., 2007; Melhem et al., 2005). Antioxidant systems, which may be classified as endogenous/exogenous or enzymatic/non-enzymatic, are in equilibrium the production of free radicals under normal conditions. Enzymatic antioxidants include the enzymes superoxide dismutase (SOD), glutathione peroxidase (GSH$P x)$, glutathione-S-transferase (GST), and glutathione reductase (GR) (Mates et al., 2000; Pham-Huy et al., 2008). Glutathione (GSH), a nonenzymatic antioxidant, is one of the most fundamental means for the protection of the body against oxidative stress (Mates et al., 2000). 
The enzymes located of the body's antioxidant defense system provide a strong defense against the destructive effects of free radicals. Although free radicals affect many compounds and molecules present on the cell membranes, their most obvious effect is to initiate lipid peroxidation. Malondialdehyde (MDA) is one of the best known aldehydes occurring as a result of lipid peroxidation. It reflects the degree of cellular damage, changes in the polymerization of cell membrane components, in enzymatic activity, in the aggregation state of the cell surface determinants, and intrinsic membrane features (Kamboh et al., 2015).

Flavonoids are polyphenols that are abundantly and widely found in phytonutrients and give plants yellow, orange, and red colors (Pikulski et al., 2003). These compounds are not produced by the body and need to be ingested (Abdel-Rahman et al., 2013; Kamboh et al., 2015). They have antioxidant properties (Urso et al., 2003). Herbal flavonoids activates appetite mechanisms in poultry and contribute to balance the gastrointestinal microflora system, and also have antiinflammatory and antioxidant effects (Goliomytis et al., 2014). Hesperidin is one of the most abundant flavonoids found in citrus species. It is an antioxidant, inhibiting lipid peroxidation and reducing oxidativestress (Jain et al., 2015; El-Shafey et al., 2014). Quercetin is a flavonoid compound that belongs to flavonol class and has strong antioxidant activity (Goliomytis et al., 2014; Sternberg et al., 2008; Boots et al., 2011). Naringin is another flavonoid found mainly in grapefruit and other citrus fruits. Naringin is also a strong antioxidant that has protective effects against metal chelation and lipid peroxidation, acting as a free radical scavenger. In addition, due to their blood cholesterol-lowering effect, flavonoids can improve the health status of laboratory animals and prolong the shelf life of poultry products (Ali et al., 2014; Jeon et al., 2002; Lee et al., 2001). This experiment was conducted to compare the antioxidant and cholesterol-reducing effects of hesperidin, quercetin, and naringin in laying chickens.

\section{MATERIALS AND METHODS}

\section{Animals, Diets, and Experimental Design}

Ninety-six 28-week-old Lohmann White laying hens with $1.5 \mathrm{~kg}$ average body weight were housed in tier cages $(50 \times 46 \times 46 \mathrm{~cm}$, with 4 chickens per cage). After a 1-wk adaptation period, birds were randomly distributed into four treatment groups, with six replicates each. The experimental unit was a cage housing four birds.

Treatments consisted of a basal diet or the basal diet with the inclusion of hesperidin ( $80 \%, \mathrm{HPLC})$, naringin (90\% from citrus fruit), or quercetin (97\%, HPLC) at a rate of $0.5 \mathrm{~g} / \mathrm{kg}$ (Sigma-Aldrich, St. Louis, $\mathrm{MO})$. The basal diet was formulated to meet nutrient requirements proposed by NRC (1994) (Table 1). During the experimental period ( $8 \mathrm{wks}$ ), layers were exposed to a 17-h daily photoperiod and were offered feed and water ad libitum.

Table 1 - Ingredient composition and chemical analysis of the basal diet.

\begin{tabular}{|c|c|c|c|}
\hline Ingredient & $\mathrm{g} / \mathrm{kg}$ & Chemical composition & \\
\hline Corn & 596.3 & Dry matter (\%) & 88.36 \\
\hline Soybean meal (46\% CP) & 195.0 & Crude protein (\%) & 17.58 \\
\hline Sunflower meal (36\% CP) & 74.0 & Crude fiber (\%) & 3.19 \\
\hline Soybean oil & 14.9 & Fat $(\%)$ & 3.75 \\
\hline Meat and bone meal & 15.0 & Crude Ash (\%) & 13.77 \\
\hline Monacalcium phosphate & 0.7 & Calcium (\%) & 3.80 \\
\hline Marble & 95.0 & Phosphorus (\%) & 0.47 \\
\hline Vitamin and mineral premix ${ }^{1}$ & 3.0 & Metabolizable energy (MJ/kg) (kkal/kg) & 11.40 \\
\hline Salt ( $\mathrm{NaCl})$ & 2.0 & & \\
\hline Sodium bicarbonate & 1.5 & & \\
\hline Toxin Binder ${ }^{2}$ & 1.0 & & \\
\hline Organic acid mixture ${ }^{3}$ & 1.0 & & \\
\hline Methionine $^{4}$ & 0.6 & & \\
\hline
\end{tabular}

${ }^{1}$ The premix provided per $1 \mathrm{~kg}$ of diet: $1.200 \mathrm{mg}$ Vitamin A retinol; $20 \mathrm{mg}$ cholecalciferol (Vit $\mathrm{D}_{3}$ ); $10.000 \mathrm{mg} \alpha$-tocopheryl acetate (Vit E); 1.333 mg menadione sodium (Vit $\mathrm{K}_{3}$ ); 1.000 mg thiamine mononitrate $\left(V_{i t} B_{1}\right) ; 1.667$ mg riboflavin (Vit $\left.B_{2}\right) ; 8.333$ mg niacin (Vit $\left.B_{3}\right) ; 3.333$ mg Ca-D- panthotenic acid (Vit $\left.B_{5}\right) ; 1.667$ mg pyridoxine (Vit $\left.B_{6}\right) ; 333$ mg folic acid (Vit $\mathrm{B}_{9}$ ); 5 mg cyanocobalamin (Vit $\mathrm{B}_{12}$ ); $15 \mathrm{mg}$ D-biotin (Vit H); $16.667 \mathrm{mg}$ (Vit ascorbic acid (C); 100.000 mg Choline chloride; 200 mg Lutein; $12.5 \mathrm{mg}$ zeaxanthin; 26.667 mg manganese oxide; 20.000 mg zinc oxide; 1.667 mg copper sulfate; 67 mg cobalt carbonate; 333 mg calcium iodate; 50 mg sodium selenite; 300 mg hydroxy methionine.

${ }^{2}$ Contained sepiolite, $1000.000 \mathrm{mg} / \mathrm{kg}$ (Mycobond, Optivite, Nottinghamshire, United Kingdom).

${ }^{3}$ Contained formic acid $35.000 \mathrm{mg} / \mathrm{kg}$; ammonium propionate, $85.000 \mathrm{mg} / \mathrm{kg}$; ammonium formate $160.000 \mathrm{mg} / \mathrm{kg}$; propionic acid, $20.000 \mathrm{mg} / \mathrm{kg}$; sodium aluminosilicate as carrier, $700.000 \mathrm{mg} / \mathrm{kg}$ (Salgard Powder, Optivite, Nottinghamshire, United Kingdom).

${ }^{4} \mathrm{DL}$-methionine. 
Iskender H, Yenice G, Dokumacioglu E, Kaynar O, Hayirli A, Kaya A
The Effects of Dietary Flavonoid Supplementation on the Antioxidant Status of Laying Hens

\section{Sample Collections and Laboratory Analyses}

At the end of the experiment, blood samples (5.0 $\mathrm{mL}$ ) were collected from the axillary vein from all hens into non-heparinized tubes using sterilized needles. Blood samples were incubated at $37^{\circ} \mathrm{C}$ for $2 \mathrm{~h}$ and then centrifuged at $1,500 \mathrm{~g}$ at $4^{\circ} \mathrm{C}$ for $10 \mathrm{~min}$. The serum samples were stored in $1.5 \mathrm{~mL}$ Eppendorf tubes at $-80^{\circ} \mathrm{C}$ for the determination of total protein, total cholesterol, and MDA levels.

Additional blood samples were collected from axillary vein by venous puncture into heparinized tubes to determine the activities of GR, GSH-Px, GST, and SOD and the level of GSH in erythrocyte lysates. After centrifugation at 1,000 $\mathrm{g}$ for $15 \mathrm{~min}$, the supernatant was removed and erythrocytes were washed three times with saline solution. A known volume of the erythrocytes was lysed with hypotonic phosphate buffer $(\mathrm{pH}$ 7.4). The hemolysate was separated by centrifugation at 2,500 $\mathrm{g}$ for $15 \mathrm{~min}$ at $2^{\circ} \mathrm{C}$.

Total Protein Concentration. Four hundred $\mu \mathrm{L}$ of 2x Lowry concentrate [3 volumes of copper reagent (20 g sodium carbonate, $0.4 \mathrm{~g}$ cupric sulfate (hydrated $5 \mathrm{x}$ ), and $0.2 \mathrm{~g}$ sodium potassium tartrate in $300 \mathrm{~mL}$ water) +1 volume of $1 \%$ sodium dodecyl sulfate + 1 volume of $1 \mathrm{M} \mathrm{NaOH}$ ] was added to $10 \mu \mathrm{L}$ serum samples, mixed thoroughly, and incubated at $25^{\circ} \mathrm{C}$ for $10 \mathrm{~min}$. Then, $200 \mu \mathrm{L}$ of $0.2 \mathrm{~N}$ folin reagent was added and immediately vortexed. The solution was incubated at $25^{\circ} \mathrm{C}$ for $30 \mathrm{~min}$ and the absorbance was read at $750 \mathrm{~nm}$. Results were calculated by using a standard albumin solution (5 g/dL) (Lowry et al., 1951).

Total Cholesterol Concentration. A volume of $1000 \mu \mathrm{L}$ of total cholesterol assay reagent [horseradish peroxidase $166.7 \mu \mathrm{kat} / \mathrm{L}$, phenol $5.2 \mathrm{mmol} / \mathrm{L}$, cholesterol oxidase $3.3 \mu \mathrm{kat} / \mathrm{L}$, cholesterol esterase 3.3 $\mu \mathrm{kat} / \mathrm{L}$, 4-aminoantipyrine $0.31 \mathrm{mmo} / \mathrm{L}$, in $103 \mathrm{mmo} / \mathrm{L}$ phosphate buffer ( $\mathrm{pH}$ 6.5)] was added to $10 \mu \mathrm{L}$ serum samples. Tubes were incubated at $37^{\circ} \mathrm{C}$ for $15 \mathrm{~min}$. Absorbance was measured at $500 \mathrm{~nm}$ against the blank reagent. Results were calculated by using a standard cholesterol solution (50 mg/dL) (Allain et al., 1974).

Antioxidant Status. Serum MDA levels (nmol/ $\mathrm{mL}$ ) were measured at $532 \mathrm{~nm}$ wavelength using the spectrophotometric method (Ohkawa et al., 1979). Erythrocyte SOD activity is based on the spectrophotometric measurement of the color intensity, resulting from the release of superoxide anion $\left(\mathrm{O}^{2} \bullet-\right)$ by the action of xanthine-xanthine oxidase and then reaction of the anion with nitroblue tetrazolium (NBT). The reaction is inhibited according to CuZn-SOD activity ( $\mathrm{U} / \mathrm{g}$ hemoglobin) in the medium, and the inhibition \% is then calculated (Sun et al., 1988). Erythrocyte GSH levels ( $\mu \mathrm{mol} \mathrm{g} /$ hemoglobin) were measured at $412 \mathrm{~nm}$ wavelength using the spectrophotometric method (Beutler et al., 1975). Erythrocyte GST activity (U/g hemoglobin) was measured by monitoring the increase in absorbance at $340 \mathrm{~nm}$, using 1-chloro-2,4-dinitro benzene as substrate (Habig et al., 1974). In the GSHPx activity assay, glutathione reduced in the presence of $\mathrm{H}_{2} \mathrm{O}_{2}$ is oxidized to oxidized glutathione (GSSG) by GSH-Px. Reduced nicotinamide adenine dinucleotide phosphate (NADPH) in the medium was used during the transformation to GSH through the GR enzyme of the oxidized GSSG. The NADPH consumption was measured at $340 \mathrm{~nm}$ wavelength in the form of decrease in absorbance. GSH-Px activity was expressed as U/g hemoglobin (Beutler, 1984). GR catalyzes the reduction of GSSG to GSH by NADPH. The GR activity (U/g hemoglobin) was determined by measuring the absorbance difference of NADPH oxidized during the reaction at $37^{\circ} \mathrm{C}$ and then reading at $340 \mathrm{~nm}$ wavelength (Andersen et al., 1997).

\section{Statistical Analysis}

One-way analysis of variance was used to evaluate the effect of treatments. Means were compared by the LSD test (SPSS 10.01, SPSS Inc., Chiago, IL). Statistical significance was declared at $\mathrm{P}<0.05$.

\section{RESULTS}

Changes in serum metabolites in response to the dietary supplementation with flavonoids are shown in Table 2. In comparison with the control group, serum protein concentration was the lowest in the hesperidin group, whereas it remained unchanged in the naringin and quercetin groups. Dietary naringin supplementation did not affect serum cholesterol

Table 2 - Effect of dietary hesperidin, naringin and quercetin supplementation $(0.5 \mathrm{~g} / \mathrm{kg})$ on serum total protein ( $\mathrm{g} / \mathrm{dL})$ and cholesterol (mg/dL) level of laying hens

\begin{tabular}{llll}
\hline Parameter & Control & Hesperidin & Naringin \\
Total protein & $4.90 \pm 0.03^{\mathrm{a}}$ & $4.80 \pm 0.03^{\mathrm{b}}$ & $4.89 \pm 0.03^{\mathrm{a}}$ \\
Cholesterol & $199 \pm 2^{\mathrm{a}}$ & $179 \pm 2^{\mathrm{a}}$ & $200 \pm 2^{\mathrm{a}}$ \\
\hline
\end{tabular}

*Results are expressed as mean \pm SE ( $n=6$ per group). Different superscripts within the same columns differ $(p<0.05)$. 
concentration, whereas dietary hesperidin and quercetin supplementations reduced serum cholesterol concentration compared with the control diet.

Table 3 shows the effects of dietary hesperidin, naringin, and quercetin supplementation on the antioxidant status and antioxidant enzymes. All flavonoids reduced serum MDA concentration compared with the control group, with stronger effects of naringin and quercetin relative to hesperidin. All flavonoids increased the activities of GSH, GSHPx, GR, and GST. Dietary hesperidin and naringin supplementation did not affect SOD activity, whereas dietary quercetin supplementation increased SOD activity. Quercetin promoted stronger activation of antioxidant enzymes than hesperidin and naringin.

\section{DISCUSSION}

Flavonoids are effectively used as supplemental agents to enhance the antioxidant status and boost the immune system (Kim et al., 2004; Wilmsen et al., 2005; Goliomytis et al., 2014). Free radicals increase as oxygen consumption increases, and are neutralized by a defense system including enzymatic and nonenzymatic antioxidants (Göktepe $\mathrm{M}$ et al., 2014). The enzymes SOD, GSH-Px, GST, and GR are the primary antioxidants of the enzymatic system and act at cellular level. Considering non-enzymatic antioxidants, GSH is the main intracellular redox buffer, and functions as a direct free radical scavenger, a co-substrate for GPx activity and a co-factor of many enzymes. It is also involved in the maintenance of exogenous antioxidants. The notable decline in the key cellular non-enzymatic antioxidant defense system considerably increases the susceptibility to oxidative stress (Rajadurai et al., 2009; Pradeep et al., 2008; Amália et al., 2007).

A number of researchers have evaluated the antioxidant activity and radical scavenging properties of flavonoids, including hesperidin (Tirkey et al., 2005; Jovanovic et al., 1994; Suarez et al., 1998), naringin (Mahmoud et al., 2012), and quercetin (Rajadurai et al., 2009; Pradeep et al., 2008), using a variety of assay systems. Sahu et al. (2013) indicated that oral hesperidin administration significantly increased serum levels of GSH, GST, GR and GSH-Px as well as decreased the expression of lipid peroxidation in rats. It was reported that serum SOD levels were relatively high after hesperidin supplementation, resulting in a reduced superoxide anion concentration in laying hens (Lien et al., 2008). In another study, the incorporation of hesperidin in the diet increased SOD activity in laying hens (Ting et al., 2011). In our work, GSH levels increased along with SOD, GR, GPx, and GST activities, especially in the quercetin group (Table 3 ). In response to supplemental flavonoids, increased enzyme activities may suggest that birds had greater capacity to clear oxygen free radicals, resulting in lower MDA level (Wilmsen et al., 2005; Rahman, 2007; Goliomytis et al., 2014). As a by-product of lipid peroxidation, MDA reflects the degree of oxidation in the body. The administration of hesperidin, naringin, and quercetin may boost the immune response and improve the wellbeing (Tang et al., 2012), by promoting cellular defense activity against oxidative stress (Karasu et al., 2014). Moreover, in agreement with the literature (Selvakumar et al., 2013), the dietary supplementation of hesperidin and quercetin decreased serum cholesterol and protein concentrations (Table 2).

In summary, all evaluated flavonoids (hesperidin, naringin, and quercetin) exerted antioxidant activity, as shown by the increased levels enzymatic and nonenzymatic defense system parameters and reduced lipid peroxidation level in laying chickens. Among these flavonoids, quercetin promoted the best results. Therefore, its utilization as a dietary additive for laying hens, especially under stress conditions, may help maintain their productivity and health status.

\section{ACKNOWLEDGMENTS}

This work was supported by the Department of Science Research Project at Artvin Coruh University.

Table 3 - Effect of dietary hesperidin, naringin, and quercetin supplementation $(0.5 \mathrm{~g} / \mathrm{kg})$ on the antioxidant status of laying hens*

\begin{tabular}{lcccc}
\hline Parameter & Control & Hesperidin & Naringin & Quercetin \\
\hline MDA $(\mathrm{nmol} / \mathrm{mL})$ & $119 \pm 3^{\mathrm{a}}$ & $96.9 \pm 2.7^{\mathrm{b}}$ & $80.9 \pm 2.1^{\mathrm{c}}$ & $75.1 \pm 1.7^{\mathrm{c}}$ \\
GSH $(\mathrm{\mu g} / \mathrm{g} \mathrm{Hb})$ & $1.39 \pm 0.04^{\mathrm{d}}$ & $2.51 \pm 0.13^{\mathrm{a}}$ & $2.03 \pm 0.07^{\mathrm{b}}$ & $1.66 \pm 0.09^{\mathrm{c}}$ \\
GSH Px $(\mathrm{U} / \mathrm{g} \mathrm{Hb})$ & $29.6 \pm 2.1^{\mathrm{c}}$ & $122 \pm 4^{\mathrm{b}}$ & $136 \pm 7^{\mathrm{b}}$ & $157 \pm 7^{\mathrm{a}}$ \\
GR $(\mathrm{U} / \mathrm{g} \mathrm{Hb})$ & $5.99 \pm 0.38^{\mathrm{c}}$ & $14.1 \pm 0.6^{\mathrm{b}}$ & $4.7 \pm 0.6^{\mathrm{a}}$ & $13.6 \pm 0.6^{\mathrm{b}}$ \\
GST $(\mathrm{U} / \mathrm{g} \mathrm{Hb})$ & $2.22 \pm 0.14^{\mathrm{b}}$ & $4.63 \pm 0.16^{\mathrm{a}}$ & $4.54 \pm 0.24^{\mathrm{a}}$ & $4.24 \pm 0.22^{\mathrm{a}}$ \\
SOD $(\mathrm{U} / \mathrm{g}$ protein) & $247 \pm 7^{\mathrm{b}}$ & $263 \pm 8^{\mathrm{b}}$ & $254 \pm 6^{\mathrm{b}}$ & $295 \pm 6^{\mathrm{a}}$
\end{tabular}

" Results are expressed as mean $\pm S E$ ( $n=6$ per group). Different superscripts within the same columns differ ( $p<0.05)$. MDA, malondialdehyde; GSH, glutathione; GSH Px, glutathione peroxidase; GR, glutathione reductase; GST, glutathione S transferase; SOD, superoxide dismutase. Hb, hemoglobin. 
Iskender $\mathrm{H}$, Yenice $\mathrm{G}$, Dokumacioglu $\mathrm{E}$, Kaynar O, Hayirli A, Kaya A
The Effects of Dietary Flavonoid Supplementation on the Antioxidant Status of Laying Hens

\section{REFERENCES}

Abdel-Rahman HA, Shawky SM, Ouda H, Nafeaa AA, Orabi SH. Effect of two probiotics and bioflavonoids supplementation to the broilers diet and drinking water on the growth performance and hepatic antioxidant parameters. Global Veterinaria 2013;10:734-741.

Allain CC, Poon LS, Chan CS, Richmond W, Fu PC. Enzymatic determination of total serum cholesterol. Clinical Chemistry 1974;20(4):470-475.

Ali MM, El Kader MA. The influence of naringin on the oxidative state of rats with streptozotocin-induced acute hyperglycaemia. Zeitschrift fxür Naturforschung. C, A Journal of Biosciences 2004;59(9-10):726-733.

Amália PM, Possa MN, Augusto MC, Francisca LS. Quercetin prevents oxidative stress in cirrhotic rats. Digestive Diseases and Sciences 2007;52(10):2616-2621

Andersen HR, Nielsen JB, Nielsen F, Grandjean. P. Antioxidative enzyme activities in human erythrocytes. Clinical Chemistry 1997;43(4):562568.

Beutler E. Reduced glutathione (GSH). In: Beutler E, editor. Red cell metabolism a manual of biochemical methods. New York: Grune and Straton; 1975a.

Beutler E. Glutathione peroxidase. In: Beutler E, editor. Red cell metabolism: A manual of biochemical methods. London, UK: Grune \& Stratton; 1984. p.74-76

Boots AW, Drent M, De Boer VC, Bast A, Haenen GR. Quercetin reduces markers of oxidative stress and inflammation in sarcoidosis. Clinical Nutrition 2011;30(4):506-512.

El-Shafey MM, Abd-Allah GM. Hesperidin improves lipid profile and attenuates oxidative stress in hypercholesterolemic rats. International Journal of Pharma Sciences 2014;4:554-559.

Ertaş ON, Güler T, Çiftçi M, Dalkılıç B, Şimşek ÜG. The effect of an essential oil mix derived from oregano, clove and anise on broiler performance. International Journal of Poultry Science 2005;4:879-884.

Florou-Paneri P, Palatos G, Govaris A, Botsoglou D, Gianneas I, Ambrosiadis I. Oregano herb versus oregano essential oil as feed supplements to increase the oxidative stability of turkey meat. International Journal of Poultry Science 2005;4:866-871

Goliomytis M, Orfanou $H$, Petrou E, Charismiadou MA, Simitzis PE, Deligeorgis SG. Effect of hesperidin dietary supplementation on hen performance, egg quality and yolk oxidative stability. British Poultry Science 2014;55(1):98-104.

Goliomytis M, Tsoureki D, Simitzis PE, Charismiadou MA, Hager Theodorides $A L$, Deligeorgis SG. The effects of quercetin dietary supplementation on broiler growth performance, meat quality, and oxidative stability. Poultry Science 2014;93(8):1957-1962.

Göktepe M, Günay M. The effect of quercetin administration on exercise, free radical and antioxidant enzyme levels. International Journal of Science Culture and Sport 2014;1:775-788.

Habig WH, Pabst MJ, Jakoby WB. Glutathione S-transferases. The first enzymatic step in mercapturic acid formation. The Journal of Biological Chemistry 1974;249(22):7130-7139.

Jain DP, Somani RS. Antioxidant potential of hesperidin protects gentamicin induced nephrotoxicity in experimental rats. Austin Journal of Pharmacology and Therapeutics 2015;3:1071.

Jeon SM, Bok SH, Jang MK, Kim YH, Nam KT, Jeong TS, et al. Comparison of antioxidant effects of naringin and probucol in cholesterol-fed rabbits. Clinica Chimica Acta 2002;317(1/2):181-90
Jovanovic SV, Steenken S, Tosic M, Marjanovic B, Simic MG. Flavonoids as anti-oxidants. Journal of The American Chemical Society $1994 ; 116(11): 4846-4851$

Kamboh AA, Arain MA, Mughal MJ, Zaman A, Arain ZM, Soomro AH. Flavonoids: Health promoting phytochemicals for animal production-a review. Journal of Animal Health and Production 2015;3(1):6-13.

Karasu K, Ozturk E. Antimicrobial and antioxidant effects of medicinal and aromatic plants in poultry. Turkish Journal of Agricultural and Natural Sciences 2014;2:1766-72

Kim JY, Jung KJ, Choi JS, Chung HY. Hesperetin:a potent antioxidant against peroxynitrite. Free Radical Research 2004;38(7):761-9.

Lee $\mathrm{CH}$, Jeong TS, Choi YK, Hyun BH, Oh GT, Kim EH, et al. Anti-atherogenic effect of citrus flavonoids, naringin and naringenin, associated with hepatic CAT and aortic VCAM-1 and MCP-1 in high cholesterolfed rabbits. Biochemical and Biophysical Research Communications 2001;284(3):681-8

Lien TF, Yeh HS, Su WT. Effect of adding extracted hesperetin, naringenin and pectin on egg cholesterol, serum traits and antioxidant activity in laying hens. Archives of Animal Nutrition 2008;62(1):33-43.

Lowry $\mathrm{OH}$, Roseberough NJ, Farr AL, Randall RJ. Protein measurement with the folin phenol reagent. The Journal of Biological Chemistry $1951 ; 193(1): 265-75$.

Mahmoud AM, Ashour MB, Abdel-Moneim A, Ahmed OM. Hesperidin and naringin attenuate hyperglycemia-mediated oxidative stress and proinflammatory cytokine production in high fat fed/streptozotocininduced. Journal of Diabetes and Its Complications 2012;26(6):483490.

Matés JM. Effects of antioxidant enzymes in the molecular control of reactive oxygen species toxicology. Toxicology 2000;153(1-3):83-104.

Melhem A, Stern M, Shibolet O, Israeli E, Ackerman Z, Pappo O, et al. Treatment of chronic hepatitis $C$ virus infection via antioxidants:Results of a phase I clinical trial. Journal of Clinical Gastroenterology 2005;39(8):737-42

NRC - National Research Council. Nutrient requirements of poultry. 9th ed. Washington;

Ohkawa H, Ohishi N, Yagi K. Assay for lipid peroxides in animals and tissues by thiobarbituric acid reaction. Analytical Biochemistry 1979;95(2):351358.

Pham-Huy LA, He H, Pham-Huy C. Free radicals, antioxidants in disease and health. International Journal of Biomedical Science 2008;4(2):89-96.

Pikulski M, Brodbelt JS. Differentiation of flavonoid glycoside isomers by using metal complexation and electrospray ionization mass spectrometry. Journal of the American Society for Mass Spectrometry 2003;14(12):1437-53

Pradeep K, Park SH, Ko KC. Hesperidin a flavanoglycone protects against gamma-irradiation induced hepatocellular damage and oxidative stress in Sprague-Dawley rats. European Journal of Pharmacology 2008; $587(1-3): 273-80$

Rahman K. Studies on free radicals, antioxidants, and co-factors. Clinical Interventions in Aging 2007;2(2):219-36

Rajadurai M, Prince PS. Naringin ameliorates mitochondrial lipid peroxides, antioxidants and lipids in isoproterenol-induced myocardial infarction in wistar rats. Phytotherapy Research 2009;23(3):358-62

Sahu BD, Kuncha M, Sindhura GJ, Sistla R. Hesperidin attenuates cisplatininduced acute renal injury by decreasing oxidative stress, inflammation and DNA damage. Phytomedicine 2013;20(5):453-60. 
Selvakumar K, Bavithra S, Suganya S, Ahmad Bhat F, Krishnamoorthy $\mathrm{G}$, Arunakaran J. Effect of quercetin on haematobiochemical and histological changes in the liver of polychlorined biphenyls-induced adult male wistar rats. Journal of Biomarkers 2013;2013:1-12.

Sternberg Z, Chadha K, Lieberman A, Hojnacki D, Drake A, Zamboni P, et al. Quercetin and interferon-beta modulate immune response(s) in peripheral blood mononuclear cells isolated from multiple sclerosis patients. Journal of Neuroimmunology 2008;205(1-2):142-147.

Suarez J, Herrera MD, Marhuenda E. In vitro scavenger and antioxidant properties of hesperidin and neohesperidin dihydrochalcone. Phytomedicine 1998;5(6):469-473.

Sun Y, Oberley LW, Yi Y. A simple method for clinical assay of superoxide dismutase. Clinical Chemistry 1988;34(3):497-500.

Tang Y, Gao C, Xing M, Li Y, Zhu L, Wang D, et al. Quercetin prevents ethanol-induced dyslipidemia and mitochondrial oxidative damage. Food Chemical Toxicology 2012;50(5):1194-1200.
Ting S, Yeh HS, Lien TF. Effects of supplemental levels of hesperetin and naringenin on egg quality, serum traits and antioxidant activity of laying hens. Animal Feed Science and Technology 2011;163(1):59-66.

Tirkey N, Pilkhwal S, Kuhad A, Chopra K. Hesperidin, a citrus bioflavonoid, decreases the oxidative stress produced by carbon tetrachloride in rat liver and kidney. BioMed Central Pharmacology 2005;31(5):2.

Urso ML, Clarkson PM. Oxidative stress, exercise and antioxidant supplementation. Toxicology 2003;189(1-2):41-54

Valko M, Leibfritz D, Moncol J, Cronin MT, Mazur M, Telser J. Free radicals and antioxidants in normal physiological functions and human disease. International Journal of Biochemistry and Cell Biology 2007;39(1):4484.

Wilmsen PK, Spada DS, Salvador M. Antioxidant activity of the flavonoid hesperidin in chemical and biological systems. Journal of Agricultural and Food Chemistry 2005;53(12):4757-61. 